\title{
Taxonomic study on potter wasps (Hymenoptera: Vespidae: Eumeninae) of Malakand, Pakistan
}

\author{
Riaz Ahmad ${ }^{1}$, Muhammad Zahid ${ }^{1}$, Muhammad Rasool ${ }^{2}$, Mudassir \\ $\mathrm{Shah}^{3}$, Muhammad Sajid ${ }^{1 *}$, Muhammad Tariq Khan ${ }^{4}$ and Pir Habib \\ Ullah $^{1}$ \\ 1. Department of Zoology Islamia College University, Peshawar-Pakistan \\ 2. Department of Zoology, Dr. Khan Shaheed Govt: Degree College Kabal Swat-Pakistan \\ 3. Department of Zoology, Govt: Superior Science College Peshawar-Pakistan \\ 4. Department of Science and Environmental Studies, The Education University of Hong Kong, Tai Po, New \\ Territories-Hong Kong \\ *Corresponding author's email: Muhammadsajid541@gmail.com \\ Citation
}

Riaz Ahmad, Muhammad Zahid, Muhammad Rasool, Mudassir Shah, Muhammad Sajid, Muhammad Tariq Khan and Pir Habib Ullah. Taxonomic study on potter wasps (Hymenoptera: Vespidae: Eumeninae) of Malakand, Pakistan. Pure and Applied Biology. Vol. 10, Issue 1, pp132-141. http://dx.doi.org/10.19045/bspab.2021.100015

Received: 01/05/2020

Revised: 05/08/2020

Accepted: $10 / 08 / 2020$

Online First: 15/09/2020

\section{Abstract}

The present study was done in district Malakand, Khyber Pakhtunkhwa, Pakistan. This study was conducted to record the biodiversity of subfamily Eumeninae indistrict Malakand. The specimens were collected from diverse localities of Malakand through active search with the use of hand net. The captured specimens were then killed by spraying insecticides in the hand nets. The killed specimens were transferred to bottles having 95\% ethanol, cyanide and ethyl acetate. The specimens were then placed in freezer for 1 or 2 days to prevent any fungal contamination. The entomological pins were used for the pining of dead specimens. The dried wasps were labeled and transferred to insect boxes having naphthalene balls as a preservative. The dried wasps were then observed and identified up to species and subspecies level with the help of pervious published literature. A total of 7 species (Delta dimidiatipenne, Antodynerus limbatus, Rhynchium carnaticum, Allorhynchium argentatum, Katamenes dimidiatus, Antepipona sibilans and Antepipona deflenda), 3 subspecies (Delta pyriformepyriforme, Delta esuriensesuriens and Antodynerousflavesens flavesens) under 6 genera (Delta, Antodynerus, Rhynchium, Allorhynchium, Katamene and Antepipona) of the subfamily Eumeninaeare reported. These taxaare recorded for the first time from district Malakand, Khyber Pakhtunkhwa, Pakistan.

Keywords: Antepipona; Antodynerus; Allorhynchium; Delta; Katamene; Rhynchium

\section{Introduction}

The subfamily Eumeninae is the largest and diverse subfamily of the family Vespidae. It contains 3,773 species under 205 genera. The wasps belonging to this subfamily arepresent throughout the world [1]. The
Eumeninae is the primary lineage of the family Vespidae. The members of Eumeninae are generally named as "potter wasps". It is more abundant and varied group having many species as compared to other subfamilies of the Vespidae. They are 
the common predators in most ecosystems [2]. They are called potter wasps because members of genus Eumenes and other similar genera made their nest from mud [3]. Eumeninae wasps are classified in 3 tribes which are Zethini, Odynerini, and Eumenini [4]. Potter wasps are solitary wasps some species show primitive social behavior. Larvae of Eumeninae wasps are predators of many insect larvae while the adult of this subfamily feed on nectar. Eumeninae is economically very important because they are the predators of many pests. These wasps are also called mason wasps [5]. Size of the adult is about $2 \mathrm{~mm}$ to $28 \mathrm{~mm}$. Some species have Petiolate metasoma but most wasps are not Petiolate. Parategula present on mesoscutum, tarsal claws are bifid, hind coxa has longitudinal carina on dorsal side and three sub marginal cells present in forewing [6]. They cannot form colony and have no labour division. The female of solitary wasps capture the insect, paralyze their prey (insect) by stinging and bring itto their nests. Each cell in the nests of potter wasps is filled by one insect (single). The wasps lay eggs in these prey filled cells and seal them. Solitary waspsconstruct their nest from clay and mud.Spider waspsare the largest wasps among Potter wasps [7]. Some solitary wasps are burrowers in soil or wood while some species of the genera Calligaster and Zethus construct nests from plant materials [8]. The wasps of this subfamily used different methods for nest construction. One female (single female) starts the nest construction from different materials used mud or clay sometimes used vegetable and plant materials. On the basis of nests locations (habitats) Eumeninae wasps are of three types, i.e. renters, excavators and builders. Most species of this group are provisioners [9].

\section{Materials and Methods Study area}

District Malakand is located among 34-22' to $34-41$ ' north latitudes and $71-37$ ' to $72-$ 14 ' east longitudes. It is attached to district Swat by a series of hills on the east-north. It is connected to Mohmand Agency and Bajawar Agency through a range of mountains on the west and to district Dir Lower on north. It is also linked to district Bunir on east, district Charsada on south to west and district Mardan on south to east. Total area of thedistrict is about $952 \mathrm{~km}^{2}$ (District Census Report, 1998).

\section{Specimens' collection}

The specimenswere collected from diverse localities of Malakand through active search with the use of the hand net. The specimens were caught from both plan area (public parks, old and new buildings, flowering plants, agronomic crops,gardens, fruit markets, vegetable markets, fields, and other vegetation) and mountains (grasses, springs water, damp area, water stream, small, and large trees) of the Malakand. The captured specimens were then killed by spraying insecticides (Black Cobra) in the hand nets.

\section{Preservation of the specimens}

The killed specimens were transferred to bottles having $95 \%$ ethanol, cyanide and ethyl acetate. The specimens were then placed in freezer for 1 or 2 days to prevent any fungal contamination. The entomological pins were used for the pining of dead specimens. The dried wasps (specimens) were labeled and transferred to insect boxes. Naphthalene balls were present in each insect box as a preservative.

\section{Microscopy}

Specimens were observed through Stereomicroscope (Nikon Japan) to record taxonomically important structures.

\section{Photography}

Pictures of the specimens were captured through Canon camera.

\section{Specimens' identifications}


The collected wasps were observed and identified up to species and subspecies level with the help of pervious published latest literature [5, 9-21].

\section{Measurements}

The measurements of the complete body (body length), and body parts of the specimens were done through Digital Calliper.

\section{Results and Discussion}

The present study was conducted in district Malakand, Khyber Pakhtunkhwa, Pakistan. Total of 7 species Delta dimidiatipenne (de Saussure, 1852), Antodynerus limbatus (de Saussure, 1852), Rhynchium carnaticum (Fabricius, 1798), Allorhynchium argentatum (Fabricius, 1804), Katamenes dimidiatus (Brulle 1832), Antepipona sibilans (Cameron, 1903), Antepipona deflenda (Saunders, 1853) and 3 subspecies Delta pyriformepyriforme (Fabricius, 1775), Delta esuriensesuriens (Fabricius, 1787), Antodynerousflavesens flavesens (Fabricius, 1775) under 6 genera Delta, Antodynerus, Rhynchium, Allorhynchium, Katameneand Antepipona of the subfamily Eumeninae were reported. All the reported species and subspecies were not previously recorded in district Malakand.

Systematic List

Order Hymenoptera

Family Vespidae

Subfamily Eumeninae

Genus: Delta de Saussure, 1885

1. Delta pyriformepyriforme (Fabricius, 1775)

2. Delta esuriensesuriens (Fabricius, 1787)

3. Delta dimidiatipenne (de Saussure, 1852)

Genus: Antodynerus de Saussure, 1855

4. Antodynerous flavesens flavesens (Fabricius, 1775)

5. Antodyneruslimbatus (de Saussure, 1852)
Genus: Rhynchium Spinola, 1806

6. Rhynchium carnaticum (Fabricius, 1798)

Genus: Allorhynchiumvan der Vecht, 1963

7. Allorhynchium argentatum (Fabricius, 1804)

Genus: Katamenes Meade-Waldo, 1910

8. Katamenes dimidiatus (Brulle 1832)

Genus: Antepipona de Saussure, 1855

9. Antepipona sibilans (Cameron, 1903)

10. Antepipona deflenda (Saunders, 1853)

Genus: Delta de Saussure, 1885

1. Delta pyriformepyriforme (Fabricius, 1775)

Material examined

Tangi Hills 1 5.iv 2018, Tangi Hills 1 ㅇ 12.iv 2018, Agra Hills 1 ㅇ 30.iv 2018, Malakand Hills 1 ते 29. vi 2018, Agra Village 1 ㅇ 1.vii 2018, Haryankot 1 ๙ 12.viii 2018, Pirano Hills 1 q 13.viii 2018, KotManzari Baba 1 ㅇ 31.viii 2018.

\section{Body measurements}

The length of the female is $23-28.4 \mathrm{~mm}$ and the length of the fore wing of female is about 22.1-22.3 $\mathrm{mm}$. The body length of male is $21.5 \mathrm{~mm}$ and the length of fore wing of male is $18 \mathrm{~mm}$.

\section{Distribution}

Pakistan, India, Nepal, Vietnam, Thailand, China, Sri Lanka, Bhutan and Myanmar (Fig. 1) [22].

\section{Remarks}

In Pakistan Delta pyriformepyriforme was earlier reported fromKhyber Pakhtunkhwa: Lower Dir: Talash [23] and from Punjab: Rawalpindi [24], Bahawalpur, Rawalpindi, Rajanpur, Jhelum, D.G. Khan, Attock, Sargodha, Bakha, Khushab, Layyah, Jhang and Muzafargarh Mianwali [6]. Gusenleitner recorded it from Islamabad [25]. Khan et al reported it from Azad Jammu and Kashmir: Poonch: Rawalakot [26]. In the current study it is first time reported from Malakand. 




Figure 1. Delta pyriformepyriforme (Fabricius, 1775)

2. Delta esuriensesuriens (Fabricius, 1787) Material examined

Tangi hills 1 o 1.v 2018, Meshta 1 i 20.v 2018, Meshta Hills 1 q 26.v 2018, Qulangi 2 o 3.vi 2018, Matkani hills 1 ô 10.vii 2018, Matkanisulgar 1 ô 29.vii 2018, Bosaq Road 1 ㅇ 30.vii 2018, Jalawanan 1 ô 19.viii 2018, Wartier1 + 25.viii 2018, KotManzarigul baba 3 + 31.viii 2018,

\section{Body measurements}

The length of the female is $17.1-18 \mathrm{~mm}$ and the fore wing length of female is 13-14.3 $\mathrm{mm}$. The length of the male is $14-15.5 \mathrm{~mm}$ and the length of the fore wing of male is 10.9-11.2 $\mathrm{mm}$.

\section{Distribution}

Pakistan, India, Iran, Mauritius, Israel, Iraq, Qatar, UAE, Indonesia, Oman, Sri Lanka, Laos, Myanmar, New Caledonia, Philippines, Vietnam, Saudia Arabia, and Thailand (Fig. 2) [22].

\section{Remarks}

It is newly reported from Malakand. Delta esuriensesuriens was earlier recorded from Pakistan: Sindh: Qambar, Ubauro, PanoAqil, Nagarpakar and Gorakh Hills [27], Khyber Pakhtunkhwa: Lower Dir: Rabat and Upper Dir: Sheringal [23], Islamabad and Punjab: Chakwal, Rawalpindi and Attock [24] and Baluchistan: Quetta [28].

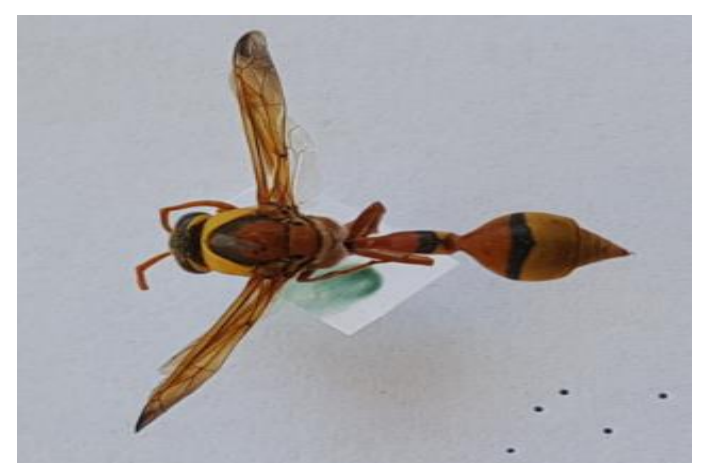

Figure 2. Delta esuriensesuriens (Fabricius, 1787)

3. Delta dimidiatipenne (de Saussure, 1852)

\section{Material Examined}

Qulangi1우 27.iv2018, Shenki Hills 1 ㅇ 28.iv 2018, Meshta Hills 2 30.iv 2018,
Qulangi Shulgar 1 † 1.v 2018, Haryankot hills 1 q 3.vi 2018, Tana2 ㅇ 7.vi 2018, Alladand 1 o 9.vi 2018,Tarayi1 क् 11.vi 2018, Bosaq 2 ㅇ 31.vii 2018, Patak 1 ㅇ 11.ix 2018. 


\section{Body measurements}

The length of the female is $25-26.2 \mathrm{~mm}$ and its fore wing is $21.5-22 \mathrm{~mm}$ while the length of male is $22.8 \mathrm{~mm}$ and the length of the fore wing of male is $21 \mathrm{~mm}$.

\section{Distribution}

India,Pakistan, Mauritania, South Africa, Oman, Egypt, Afghanistan, Sudan, Algeria, Saudi Arabia, Chad, Nepal, Djibouti, Ethiopia, Morocco, Syria, UAE, Eritrea, Uganda, Yemen, Qatar, Turkmenistan, Jordan, Iran, Niger, Turkey, Tajikistan, Spain, and Somalia [22]. UAE, North Africa, Yemen and Nepal (Fig. 3) [29].

Remarks

During this study it is first time reported from Malakand. In Pakistan, Delta dimidiatipennewas previously reported from Sindh: Larkana, Dadu city, Sukkur, Kotri, Hyderabad, Umarkot, Nagarparkar, and Korangi [27]. It was recorded from Khyber Pakhtunkhwa: Swat: Takhataband Mingora and Kabal [30] and from Khyber Pakhtunkhwa: Lower Dir: Chakdara [23]. It was described from Gilgit-Baltistan: Hunza and Ghizer [31]. In Punjab it was reported from Jhelum, Rawalpindi, Murree, Chakwal, and Attock [24]. Gusenleitner recorded from Baluchistan: Quetta [28]. Khan et al. identified fromAzad Jammu and Kashmir: Poonch and Banjosa [26].

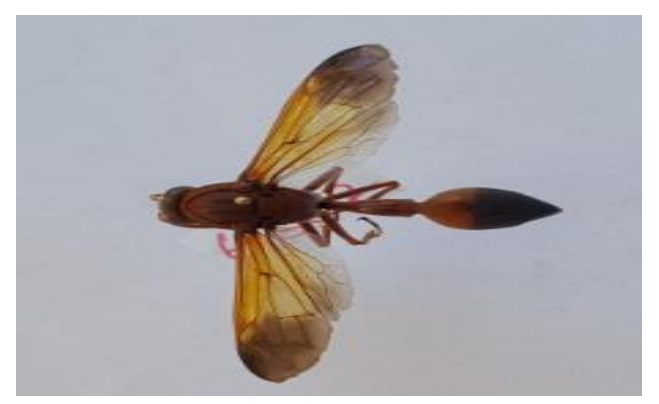

Figure 3. Delta dimidiatipenne (de Saussure, 1852)

Genus: Antodynerus de Saussure, 1855

4. Antodynerousflavesens flavesens

(Fabricius, 1775)

Material examined

Pirkhel Bica 1 q 19.vii 2018, Bosaq 2 \%

30.vii 2018, Agra Village 1 गे 3.viii 2018, Agra Hills 1 §ै 3.viii 2018.

Body measurements
The female body length is 10.5-12.2 mm and the length of female fore wing is 9$9.5 \mathrm{~mm}$ while the length of male is $11 \mathrm{~mm}$ and the fore wing length of male is $8.8 \mathrm{~mm}$.

Distribution

Pakistan, Bangladesh and India (Fig. 4) [22]. Remarks

Antodynerousflavesens flavesens was reported from Islamabad [22].

Figure 4. Antodynerousflavesens flavesens (Fabricius, 1775) 
5. Antodynerus limbatus (de Saussure, 1852)

Material examined

Shinki Hills 2 9.v 2018, Korjaba Hills 1 ㅇ 19.v 2018, Meshta Hills 1 क 26.v 2018, Kabir Hills 1 đ 4.vii 2018, AgraHils 1 우 21.vii 2018, Inzargi Hills 1 đ 3.viii 2018.

Body measurements

Length of the female is $15-15.8 \mathrm{~mm}$ and the length of the fore wing of female is 10.2-11 $\mathrm{mm}$. The length of the male body is $12 \mathrm{~mm}$ and the fore wing length is $9.7 \mathrm{~mm}$.

\section{Distribution}

Pakistan, India, China, Nepal, Myanmmar, Thailand and Laos (Fig. 5) [22].

\section{Remarks}

Earlier from Pakistan Antodynerus limbatus was described from Sindh: Dokri, Mehrabpur and ThariMirwah [27]. It was reported from Khyber Pakhtunkhwa: Abbottabad and Kashmir: Muzafarabad [22]. It was also recorded from Punjab Taxila [25].

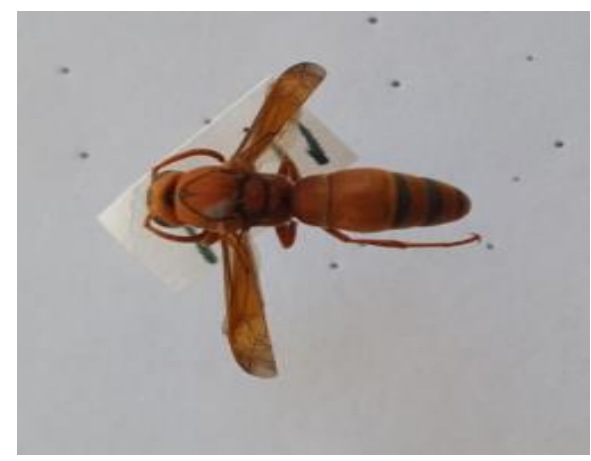

Figure 5. Antodynerus limbatus (de Saussure, 1852)

Genus: Rhynchium Spinola, 1806

6. Rhynchium carnaticum (Fabricius, 1798)

Material examined

Haryankot, 1 + 20.vii 2018

Body measurements

The length of the body is $16.8 \mathrm{~mm}$ and the length of the fore wing is $13 \mathrm{~mm}$.
Distribution

Sri Lanka, Indonesia, India and Pakistan (Fig. 6) [22].

\section{Remarks}

Rhynchium carnaticum was earlier reported from Khyber Pakhtunkwa Swat: Takhtaband [30]. This species was also previously recorded from Sindh: Karachi [16, 31].

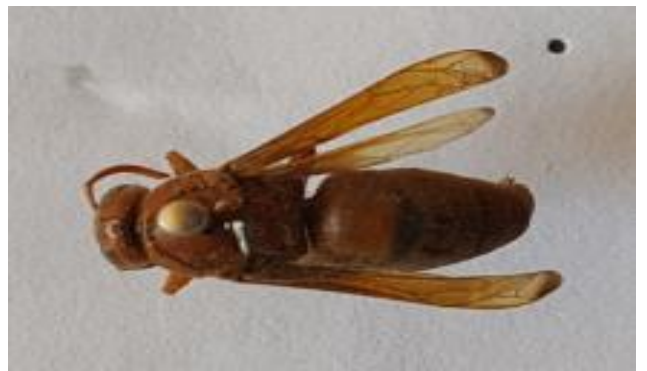

Figure 6. Rhynchium carnaticum (Fabricius, 1798)

Genus: Allorhynchiumvan der Vecht, 1963

7. Allorhynchium argentatum (Fabricius, 1804)
Material examined

Agra 1 ô 21.vii 2018

Body measurements 
The length of male is $13 \mathrm{~mm}$ and the length of fore wing of the male is $11.1 \mathrm{~mm}$.

\section{Distribution}

Malaysia, Thailand, Laos, India, Bhutan, Myanmar, Philippines, Pakistan, Nepal, Indonesia, Laos and Singapore (Fig. 7) [22].

\section{Remarks}

Previously in Pakistan Allorhynchium argentatum was recorded from Sindh: Halaji Lake, Malir and Mirpur Khas [27], Khyber Pakhtunkhwa: Lower Dir: Timergara [23],
Khyber Pakhtunkhwa: Chitral: Bronze and Kalash, From Punjab: Lahore: Changa Manga and from Gilgit-Baltistan: Skardu: City Road [22]. It was reported from Islamabad and Punjab: Chakwal Rawalpindi, Jhelum and Attock [24]. This species was also recorded from GilgitBaltistan: Skardu and Ghizer [32]. In the present study, it is a newly recorded species in Malakand.

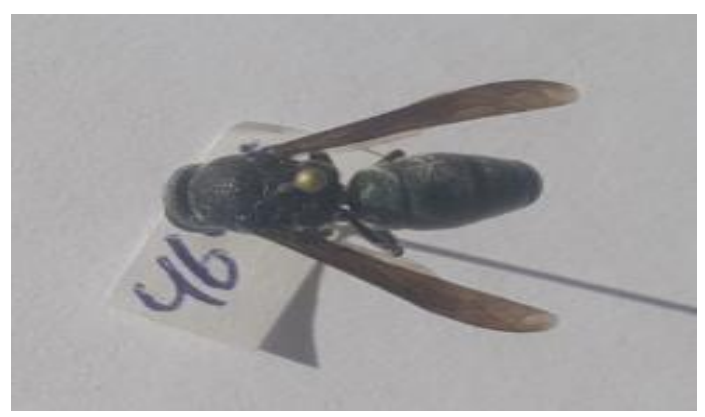

Figure 7. Allorhynchium argentatum (Fabricius, 1804)

Genus: Katamenes Meade-Waldo, 1910

8. Katamenes dimidiatus (Brulle 1832)

Material examined

Chenar gar 1 , , 6.iv 2018, Agra 19 24.iv

2018, Bosaq 1ㅇ.v 2018

Body measurements

Body length is $18.3-18.8 \mathrm{~mm}$ and the length of fore wing is $15-16 \mathrm{~mm}$.

Distribution
Iran, India, Pakistan, Afganistan, Central Asia, Kazakhastan, Turkey, Mongolia, Syria, Israel, Russia, Europe, Caucasus and Cyprus (Fig. 8) [29].

Remarks

In Malakand it is newly reported. Previously in Pakistan it was reported by Gusenleitner from Baluchistan: Quetta: Chiltan National Park and Hazarganji [28].

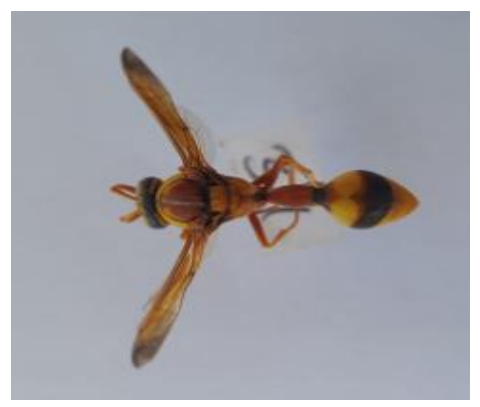

Figure 8. Katamenes dimidiatus (Brulle, 1832)

Genus: Antepipona de Saussure, 1855

9. Antepipona sibilans (Cameron, 1903) Material examined

Toti 1 q 31.vii 2018, Bosaq 1 กิ 4.viii. 2018

\section{Body measurements}

The length of the female is $7.5 \mathrm{~mm}$ and fore wing is $6 \mathrm{~mm}$. The length of the male is 7 $\mathrm{mm}$ and fore wing length is $5.8 \mathrm{~mm}$. 


\section{Distribution}

West Bangal, Pakistan, Nepal and India (Fig. 9) [22].

\section{Remarks}

In Pakistan Antepipona sibilanswas previously recorded from Sindh: Larkana,
Ratodero, Ghotkhi and Sukkur [27]. It was recorded from Khyber Pakhtunkhwa: Swat: Kabal [30]. Rafi et al. [22]described it from Punjab: Multan. From Islamabad it was reported by Siddiqui et al. [24].

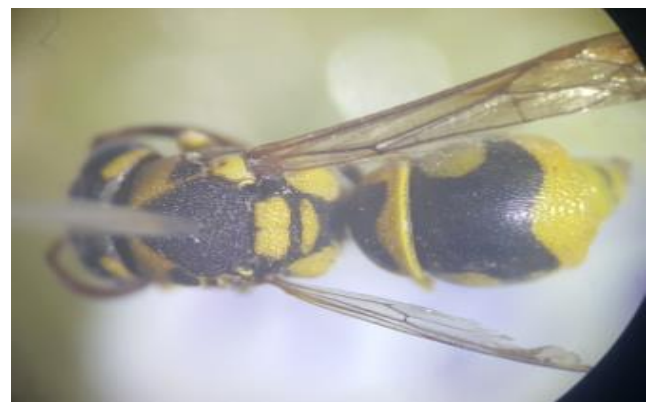

Figure 9. Antepipona sibilans (Cameron, 1903)

\section{Antepipona deflenda (Saunders, 1853)} Material examined

Chenar Gar 7 ㅇ 9.v 2018, KowarJaba3우 19.v 2018, Meshta 1 q 20.v 2018, Agra 2 ㅇ 24.v 2018, Meshta Hills 7 q 26.v 2018, Agra Hills 6 ㅇ 23.vi 2018, Meshta 1 ㅇ 1.vii 2018, Kabir Hills 2 ㅇ 4.vii 2018, Inzargi 3 ㅇ 4.vii 2018.

\section{Body measurements}

The length of the body is 7-8 $\mathrm{mm}$ while the fore wing length is $5.2-6 \mathrm{~mm}$.

Distribution
Pakistan, Tajikistan, France, Uzbekistan, Algeria, China, Iran, Israel, Kazahkstan, Montenegro, Portugal, Switzerland, Turkey, Albania, Austria, Croatia, Germany, Iraq, Italy, Jordan, Lebanon, Morocco, Russia, Spain, Slowkia, Ukraine and Czech Republic [22].

Remarks

This Species is first time recorded from Malakand. Antepiponadeflendawas earlier reported from Khyber Pakhtunkhwa: Swat: Kabal by Rasool et al. [30].

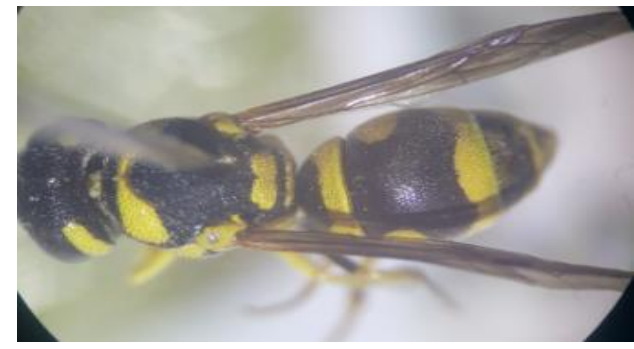

Figure 10. Antepipona deflenda (Saunders, 1853)

\section{Conclusion}

The current study reported a detail formal taxonomic description Eumeninae fauna collected from district Malakand, Khyber Pakhtunkhwa, Pakistan. A total of 7 species and 3 subspecies under 6 genera of subfamilyEumeninae are reported. The recorded subspecies and species are Delta pyriformepyriforme, Delta esuriensesuriens, Delta Antodynerousflavesens flavesens, Antodynerus limbatus, Rhynchium carnaticum, Allorhynchium argentatum, Katamenes dimidiatus, Antepipona sibilans 
and Antepipona deflenda. All the reported species and subspecies are first time recorded from district Malakand.

\section{Authors' contributions}

Collected specimens: Riaz Ahmad, Identified the specimens: $M$ Zahid, $\mathrm{R}$ Ahmad \& $M$ Rasool, Helped in the preparation of manuscript: M Sajid, M Shah, MT Khan \& P Habibullah.

\section{References}

1. Tan JI, Carpenter JM \& Achterberg CV (2018). An illustrated key to the genera of Eumeninae from china, with checklist of species (Hymenoptera, Vespidae). Zookeys 740: 109-149.

2. Carpenter JM \& Cumming JM (1985). A character analysis of the North American potter wasps (Hymenoptera: Vespidae; Eumeninae). J Nat Hist 19: 877-916.

3. Odonnell S \& Jeanne RL(2002). The nest as fortress: defensive behavior of Polybiaemaciata, a mud-nesting eusocial wasp. J Insect Sci 2: 3- 5.

4. Selis M (2018). Notes on the subfamily Stenogastrinae (Hymenoptera: Vespidae) in the Philippine islands, with description of nine new species. Zootaxa 4514(3): 383-410.

5. Nidup T, Klein W, Kumar PG \& Dorji $P$ (2018). Additional reports of solitary potter wasps (Hymenoptera:Vespidae; Eumeninae) in Bhutan. J Threat Taxa 10: 11686-11696.

6. Bodlah I, Naeem M, Khan MR, Bodlah MA \& Akhtar T (2012). Genus Delttade Saussure (Hymenoptera:Vespidae; Eumeninae) from Punjab province Pakistan. Pak J Zool 44(3): 759-764.

7. Ross HH (1948). Vespidae, yellow jacket and Hornet wasp, A text book of entomology by Herbert H. Ross. London Chapman and Hall, Limited. pp. 325-327.

8. Hermes MG, Melo GAR \& Carpenter JM (2014). The higher-level phylogenetic relations of the Eumeninae (Insecta, Hymenoptera, Vespidae), with emphasis on Eumenessensulato. Cladistics 30: 453-484.

9. Pannure A, Belavadi VV \& Carpenter JM (2016). Taxonomic studies on potter wasps (Hymenoptera: Vespidae: Eumeninae) of South India. Zootaxa 4171(1): 1-50.

10. Gawas SM, Kumar PG, Gupta A \& Sureshan PM (2019). Checklist of vespid wasps (Hymenoptera: Vespidae) of Goa, India, with new records and a key to species. Zootaxa 4585(2): 269294.

11. Dorji P, Klein W \& Nidup T (2017). Taxonomic study of social vespid wasps (Hymenoptera: Vespidae: Vespinae \& Polistinae) in Bhutan. $J$ Insect Biodivers Syst 3(2): 91-104.

12. Sheikh, AH, Kumar PG, Thomas M \&Bhandari R (2017). Taxonomic studies on Vespid Wasps (Hymenoptera: Vespoidea: Vespidae) of Dumna Nature Park, Jabalpur, Madhya Pradesh. Rec Zool Sur India 117(3): 198-213.

13. Buyanjargal B, Dorzhiev TZ, Abasheev RY \& Bataa D 2016). Geographical Range of Vespid Wasps (Hymenoptera, Vespidae) of Northern Mongolia. Mong J Biol Sci 14(1-2): 21-31.

14. Kumar GP, Carpenter JM \& Sureshan PM (2016). A taxonomic review of the genus Antepipona de Saussure, 1855 (Hymenoptera: Vespidae: Eumeninae) from India. Zootaxa 4150(5): 501-536.

15. Kumar PG \& Sharama G (2015). Taxonomic studies on vespid wasps (Hymenopter: Vespoidea: Vespidae) of Chhattisgarh, India. $J$ Threat Taxa 7(14): 8096-8127.

16. Kumar PG \& Sharma G (2014). Taxonomic Studies on vespid wasps (Vespidae: Vespoidea: Hymenoptera: Insecta) of Rajasthan, India with Six 
New Records from the State. $J$ New Biol Reports 3(3): 240 - 258.

17. Kumar PG \&Carpenter JM (2013). A taxonomic review of the genus Antodynerus de Saussure, 1855 (Hymenoptera: Vespidae: Eumeninae) from the Indian subcontinent. Zootaxa 373(2): 267-278.

18. Srinivasan G \& Kumar PG (2013). A Study on Vespid Wasps (Insecta: Hymenoptera: Vespidae) Of Itanagar Wildlife Sanctuary, Arunachal Pradesh. Rec Zool Sur India 113(1): 115-127.

19. Zhou X, Chen B \& Li T (2012). Two new species and a key to species of the genus Eumenes Latreille (Hymenoptera: Vespidae: Eumeninae) from southwestern China. Entomotaxonomia 34(2): 467-474.

20. Dvorak L \& Carpenter JM (2010). New records of vespid wasps from Yemen with synonymy in Belonogaster (Hymenoptera: Vespidae: Polistinae and Eumeninae). $\quad$ Linz Biol Beitr 42(1): 561-563.

21. Ebrahimi E \& Carpenter JM (2008). Catalog of the vespid wasps of Iran (Hymenoptera, Vespidae). Zootaxa 1785: 1-42.

22. Rafi MA, Carpenter JM, Qasim M, Shehzad A, Zia A, Khan MR, Mastoi MI, Naz F, Ilyas M, Shah M \& Bhatti AR (2017). The vespid fauna of Pakistan. Zootaxa 4362(1): 001-028.

23. Rauf SA, Rafi MA, Qasim M, Sheikh K, Mehmood K, Durrani S, Khan A \& Rahman A (2018). Wasps Fauna of Subfamilies (Eumeninae, Polistinaeand Vespinae) From Dir, Khyber Pakhtunkhwa, Pakistan. Uni Sin J Ani Sci 2(1): 1-7.

24. Siddiqui JA, Bodlah I, Carpenter JM, Naeem M, Munir A \& Bodlah MA (2015). Vespidae (Hymenoptera) of the
Pothwar region of Punjab, Pakistan. Zootaxa 3914(5): 501-524.

25. Gusenleitner J (2007). Uber Vespidaeaus Pakistan (Hymenoptera: Vespidae). Linz Biol Beitr 39(2): 969972.

26. Khan AK, Khan MR, Rafi MA \& Qasim M (2017). Wasps fauna of (Eumeninae, Vespinae and Polistinae) of District Poonch, Azad Jammu and Kashmir (Pakistan). J Entomol Zool Stud 5(6): 1587-1590.

27. Khan MT, Rafi MA, Sultana R, Munir A \& Ahmad S (2018). Wasps of Subfamilies Eumeninae, Vespinae and Polistinae from Sindh-Pakistan. $J$ Entomol Zool Stud 6(2): 892-897.

28. Gusenleitner J (2006). Uber Eumeninae, Aufgesammelt in Pakistan (Hymenoptera: Vespidae). Linz Biol Beitr 38(2): 1295-1305.

29. Rahmani Z, Akhshani E, \& Carpenter JM (2020). Updated Checklist of Vespidae (Hymenoptera: Vespoidea) in Iran. J Insect Biodivers Syst 06(1): 2786.

30. Rasool M, Zahid M \& Shah M (2017). Solitary Wasps (Hymenoptera: Vespidae: Eumeninae) of Swat Pakistan, with two species newly reported from the country and three unidentified species. J Entomol Zool Stud 5(2): 648-653.

31. Kumar PG \& Sharma G (2013). A taxonomic study on the genus Rhynchium Spinola (Hymenoptera: Vespidae: Eumeninae) from the Indian subcontinent. Zool Sur India 113(2): 105-122.

32. Faiz A, Rafi MA, Zia A, Shah A, Shah SW, Khan RU \& Saeed M (2016). Wasp fauna of (Eumeninae: Vespinae and Polistinae) in forests of GilgitBaltistan (Pakistan). Pure Appl Biol 5(4): 682-688. 